\title{
An Analysis of Distance Extension Method in Visible Light Communication (VLC) Performance
}

\section{LISA KRISTIANA ${ }^{1}$, ARSYAD RAMADHAN DARLIS ${ }^{2}$, IRMA AMELIA DEWIㄹ, LITA LIDYAWATI², HEGAR REFALDY ARCHANDHIKA ${ }^{2}$}

\author{
${ }^{1}$ Informatics Department, Institut Teknologi Nasional Bandung, Indonesia \\ Electrical Department, Institut Teknologi Nasional Bandung, Indonesia \\ Email: lisa@itenas.ac.id
}

Received 12 Desember 201x | Revised 2 Januari 2020 | Accepted 25 Januari 2020

\begin{abstract}
ABSTRAK
A Visible Light Communication (VLC) adalah teknologi yang menawarkan konsep inovatif karena VLC menerapkan cahaya tampak untuk mentransmisikan informasi dari satu titik ke titik lain. Tantangan utama dalam penerapan VLC adalah pelemahan sinyal cahaya tampak karena faktor jarak dari titik sumber ke titik tujuan. Penelitian ini berfokus pada metode untuk merancang dan menerapkan pemancar dan penerima VLC pada media udara. Dengan membandingkan berbagai macam tipe LED, pengukuran yang didapatkan menunjukkan bahwa pemancar dan penerima VLC dapat ditingkatkan kemampuannya sehingga mencapat jarak maksimum 8.5 meter dengan menggunakan LED HPL.
\end{abstract}

Kata kunci: Visible Light Communication, VLC Transceiver, Distance Extension Method, Light Emitting Diodes (LEDs).

\begin{abstract}
A Visible Light Communication (VLC) offers the innovative concept in telecommunication since it implements visible lights to transmit information from one point to other points. The main challenge in VLC is the attenuation due to the distance from source to destination. This research focuses on extension method to design and implement the VLC transceiver in an air medium. By comparing the real measurement of several types of LEDs, the distance of VLC transceiver can be extended up to 8.5 meters by applying HPL LED.
\end{abstract}

Keywords: Visible Light Communication, VLC Transceiver, Distance Extension Method, Light Emitting Diodes (LEDs). 


\section{INTRODUCTION}

Visible Light Communication (VLC) is an optical wireless communication system that has been an increasing interest in many fields such as in seashore (Darlis, A. W., 2018), and Vehicle-to-vehicle (Shen, W. H., \& Tsai, 2017), (Uysal, M., Ghassemlooy, Z., Bekkali, A., Kadri, A., \& Menouar, 2016), (Kim, Y. H., Cahyadi, W. A., \& Chung, 2015). VLC uses the high power Light Emitting Diodes (LEDs) in a visible spectrum (Ghassemlooy, Z., Arnon, S., Uysal, M., Xu, Z., \& Cheng, 2015). In order to successfully transmit data through VLC system (Sindhubala, K., \& Vijayalakshmi, 2015), (Mossaad, M. S., Hranilovic, S., \& Lampe, 2015), the LEDs on the transmitter have to be located not far from the receiver. The lower Signal-to-Noise Ratio (SNR) is obtained as the distance between transmitter and receiver is increased (Fuada, S., Putra, A. P., Aska, Y., \& Adiono, 2016), (Mossaad, M. S., Hranilovic, S., \& Lampe, 2015). Therefore, our work focuses on designing the VLC transmitter and enhancing the reception of signal (Hecht, 1997), (Max Born, 1999). The enhancement of signal reception is obtained by applying a distance extension method. This paper is structured as follow: Section 1 describes the challenge in VLC system. Section 2 provides a prototype of both VLC transmitter and reception. Section 3 evaluates the design system and analyses the output based on the distance extension method. Finally the conclusion and future work are provided in the Section 4.

\section{VLC TRANSCEIVER}

The design of VLC transceiver as the prototype is divided to two subsections as follows:

\subsection{The VLC Transmitter}

The VLC transmitter prototype (Figure 1.b) is designed according to the VLC's transmitter circuit as shown in Figure 1.a. The realization of the transmitter prototype includes only one LED in each circuitry and assembles LED's numbers when required.
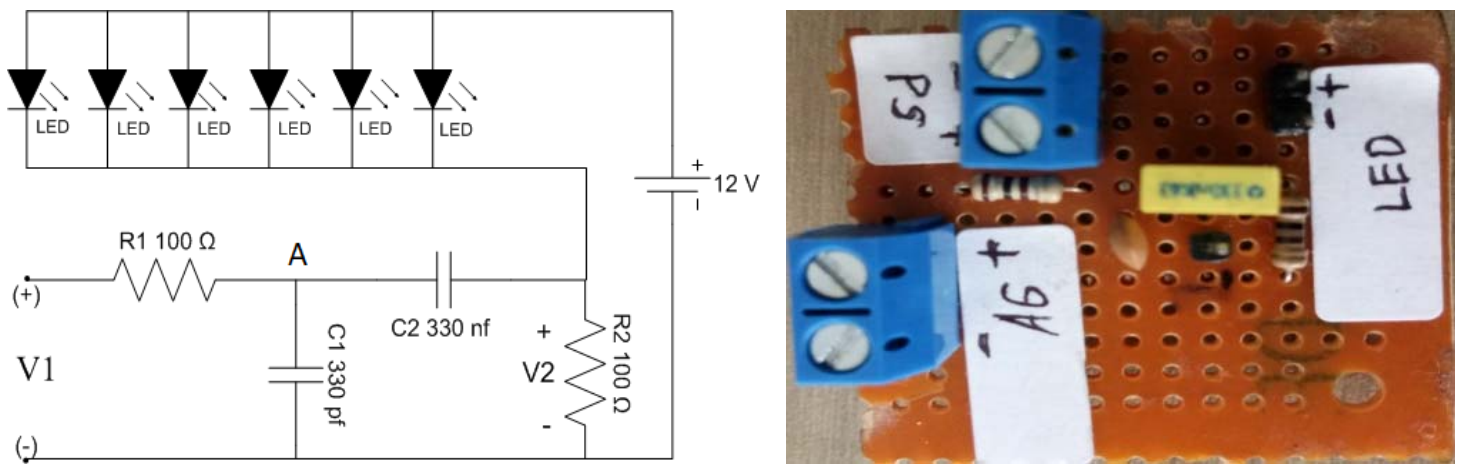

Figure 1. VLC's Transmitter (a) VLC Circuit, (b) Prototype

The transmitter sends the audio signal with the frequency of $3 \mathrm{kHz}$ through LEDs. In order to suppress the noise, the transmitting signal is filtered by a Band Pass Filter (BPF). The transmitting signal is detected by an oscilloscope that shows the output of BPF in Figure 2. 


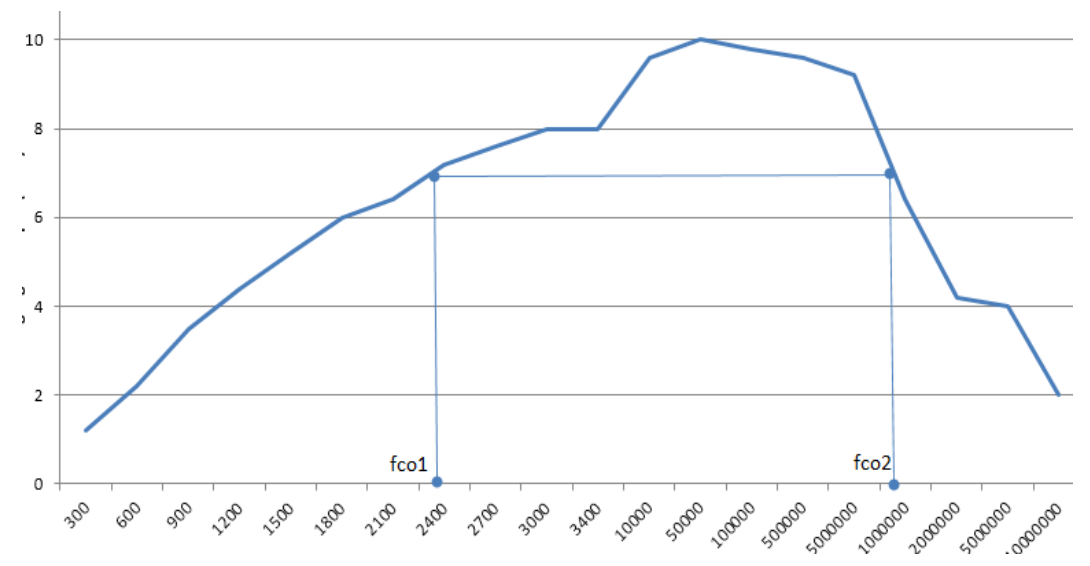

Figure 2. The Output of Band Pass Filter

Using the prototype as mentioned, the signal with a frequency of $3 \mathrm{KHz}$ is transmitted applying an equation as follows:

$$
\begin{gathered}
V_{1}-V_{2}-V_{A}(1+33 n S)=0 \\
V_{A}=\frac{100 S+\frac{1}{330 n}}{100 S} x V_{2}=\frac{S+30.3 k}{S} \times V_{2}
\end{gathered}
$$

Substituting Equation (1) and Equation (2) will have the result as follows:

$$
\begin{gathered}
f_{c 1}=\frac{\frac{\omega_{1}}{2}}{2 \pi}=\frac{15.16 \times 10^{6}}{2 \pi}=2.4 \mathrm{kHz} \\
f_{c 2}=\frac{B_{W}}{2 \pi}=\frac{60.6 \times 10^{6}}{2 \pi}=9.6 \mathrm{MHz}
\end{gathered}
$$

\subsection{The VLC Receiver}

The receiver consists of photodiode and amplifier as shown in Figure 3. This circuit receives the visible light which is subsequently converted to electrical signal. The output of the receiver is amplified with the calculation of $A v_{1}$, as follows:

$$
\begin{gathered}
I_{B}=\frac{V_{C C}-V_{b e}}{R_{B}+\beta R_{C}}=\frac{9-0.5}{56 k+(220.470 \mathrm{k})}=82.16 \mathrm{nA} \\
I_{E}=(\beta+1) I_{B}=(220+1) \times\left(82.16 \times 10^{-9}\right)=18.15 \mu \mathrm{A} \\
r_{e}=\frac{26 \mu \mathrm{V}}{I_{E}}=\frac{26 \times 10^{-3}}{18.15 \times 10^{-6}}=1432.5
\end{gathered}
$$


An Analysis of Distance Extension Method in Visible Light Communication (VLC) Performance

$$
A v_{1}=\frac{-\frac{R_{C}}{r_{e}}}{\left(1+\frac{R_{C}}{R_{B}}\right)}=\frac{-\frac{470 \times 10^{3}}{1432.5}}{\left(1+\frac{470 \times 10^{3}}{56 \times 10^{3}}\right)}=-34.9
$$

By using the similar calculation, we find $A v_{2}$, as follows:

$$
\begin{gathered}
I_{B}=\frac{V_{C C}-V_{b e}}{R_{B}}=\frac{9-0.5}{1 \times 10^{6}}=8.5 \mu A \\
I_{E}=(\beta+1) I_{B}=(220+1) \times\left(8.5 \times 10^{-6}\right)=1.88 \mu A \\
r_{e}=\frac{26 \mu V}{I_{E}}=\frac{26 \times 10^{-3}}{1.88 \times 10^{-6}}=13829.8 \\
A v_{2}=\frac{-R_{C}}{r_{e}}=\frac{-1000}{13829.8}=-0.07
\end{gathered}
$$

The similar method in designing the VLC transmitter, Figure 3 shows the realization of VLC receiver. As illustrated in Figure 3.b the Photodiode number increases in numbers when required based on the VLC receiver circuit in Figure 3.a.

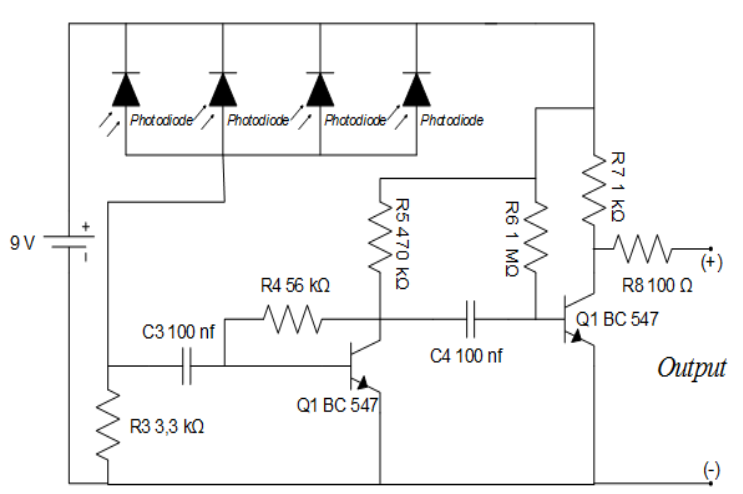

(a)

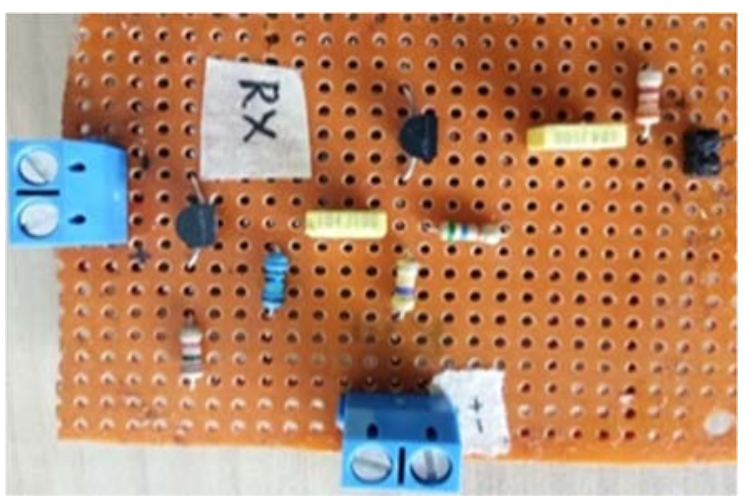

(b)

Figure 3. VLC Receiver (a) Circuit (b) Prototype

\section{EVALUATION AND ANALYSIS}

This work is conducted in 10 times measurements using parameters as shown in Table 1.

Tabel 1. Parameter Setting

\begin{tabular}{|l|l|}
\hline \multicolumn{1}{|c|}{ Description } & \multicolumn{1}{c|}{ Type/Unit } \\
\hline Transmitter & Audio \\
\hline Receiver & Audio \\
\hline LED & $5 \mathrm{~mm}, \mathrm{HPL}$ \\
\hline Distance & $1,3,5$ meters \\
\hline Reflector & $31 \mathrm{~mm}, 52 \mathrm{~mm}$ \\
\hline Photodiode Numbers & 1 and 2 \\
\hline Solar Cell & 1 \\
\hline
\end{tabular}


Those parameters are implemented in several experiments to validate 4 distance extension methods as follows:

a. Distance extension by applying different LED types

b. Distance extension by applying reflector on LED

c. Distance extension by adding photodiode number

d. Distance extension by applying solar cell

\subsection{Distance Extension by Applying Different LED Types}

The evaluation of distance extension method by applying different LED types shows signal reception captured by the oscilloscope (Figure 4.)

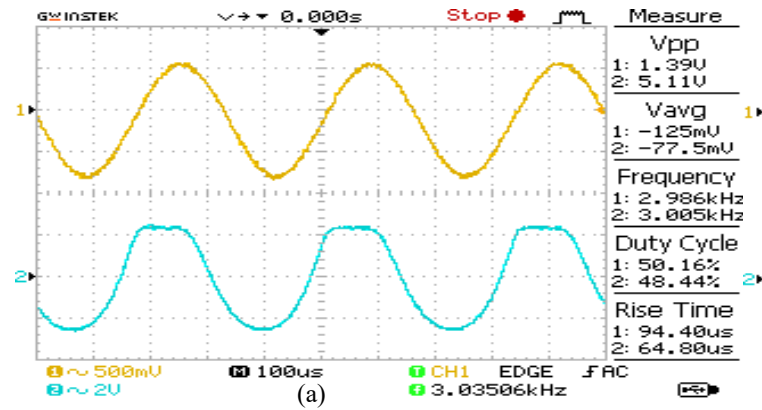

(a)

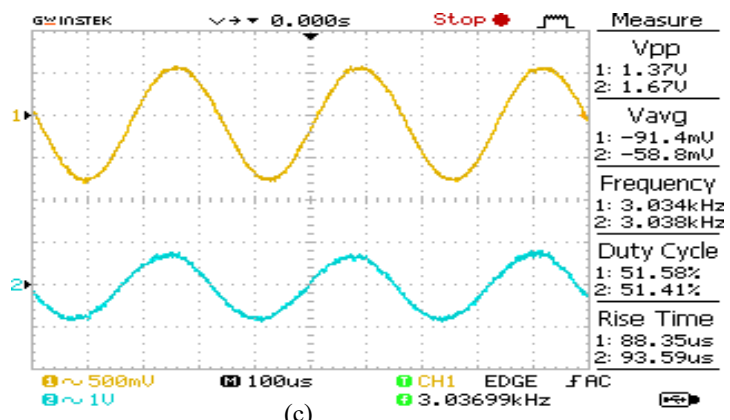

(c)

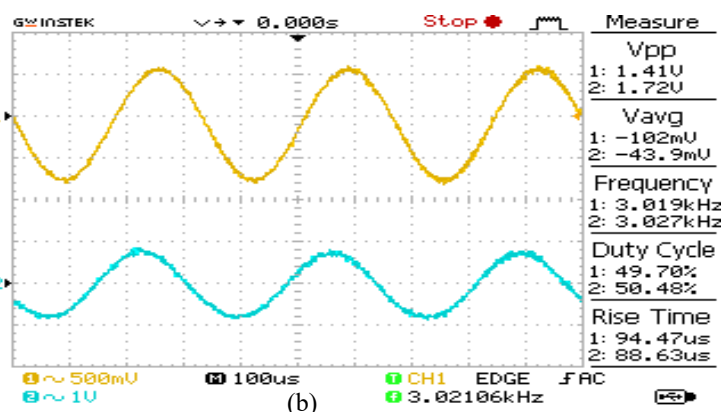

(b)

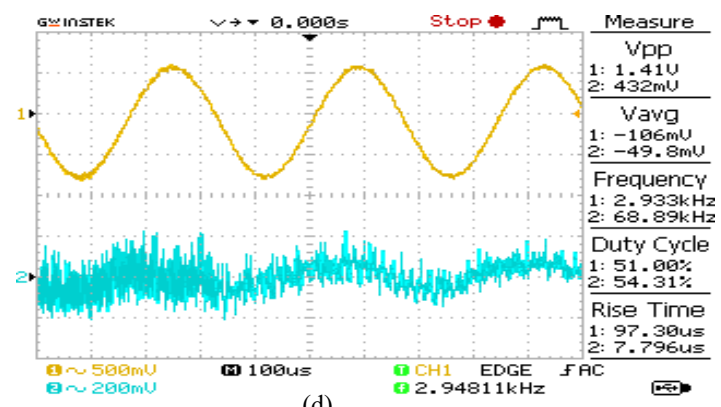

(d)

Figure 4. VLC Transceiver Signal Measurement:

(a). 1 meter $5 \mathrm{~mm}$ LED, (b). 1 meter HPL LED,

(c). 3 meters $5 \mathrm{~mm}$ LED, (d). 3 meters HPL LED

The VLC transceiver's measurement that is shown in Figure 5, indicates the signal attenuation toward the distance extension on average. By applying $5 \mathrm{~mm}$ LED type, the signal voltage remains on the $5.36 \mathrm{Vpp}$, while it drops on $1.72 \mathrm{Vpp}$ by using the HPL LED both at distance 1 meter. When the distance reaches 3 meters, the signal voltage drops to under $1 \mathrm{Vpp}$ by applying both LED types. Thus, $5 \mathrm{~mm}$ LED is more suitable than HPL LED because HPL LED experiences a narrowing signal beam. 


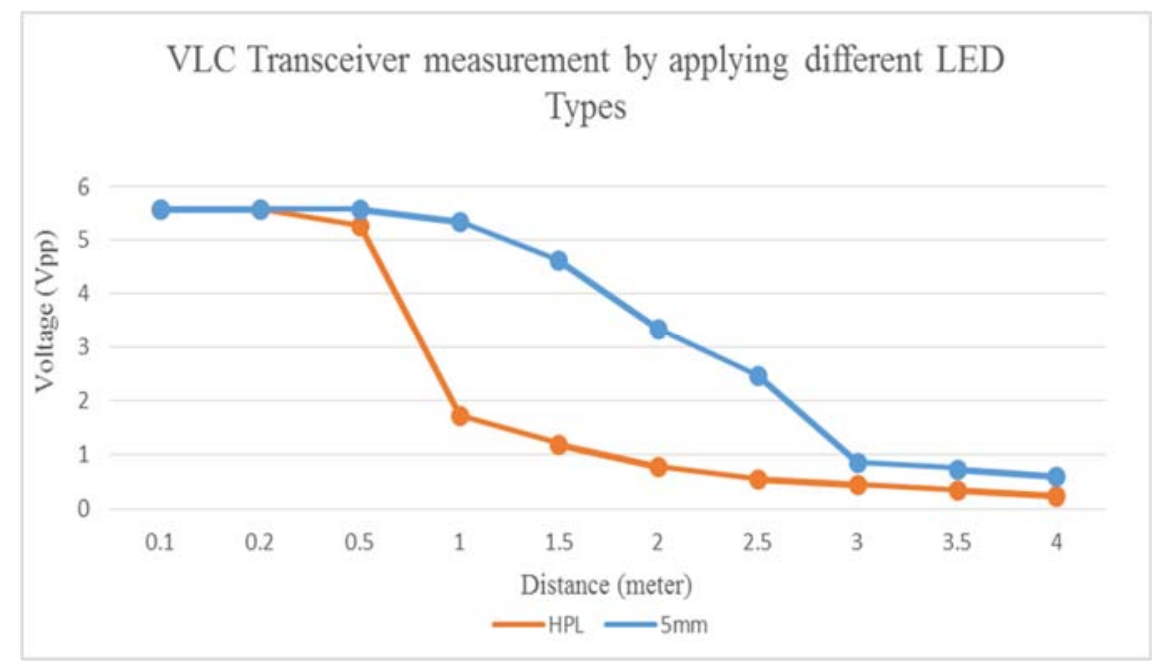

Figure 5. Signal Measurement Applying Different LED Types

\subsection{Distance Extension by Applying Reflector on LED}

This experiment evaluates the applied reflector on LED which is shown in Figure 6.

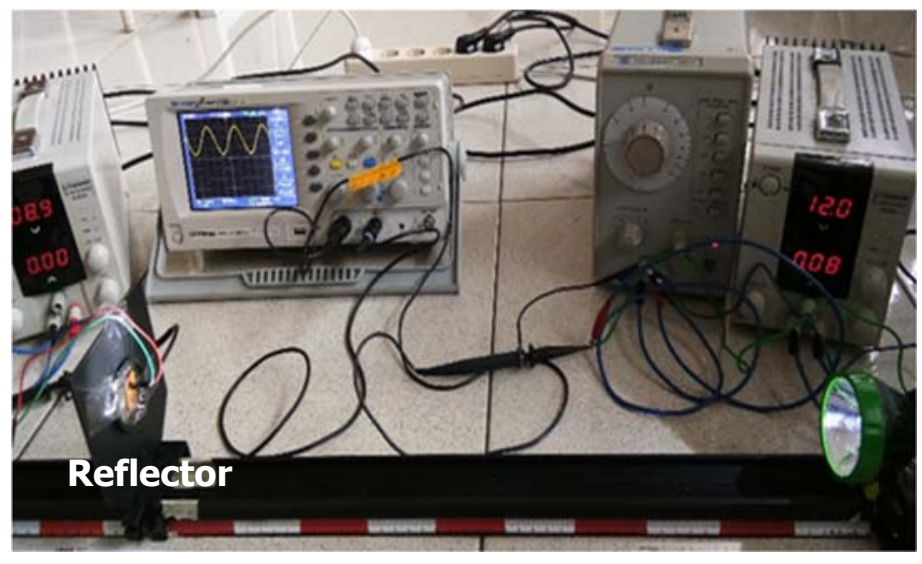

Figure 6. Implementation of reflector on LED

The implemented reflector on LED shows the measurement results on the oscilloscope as illustrated in Figure 7. 


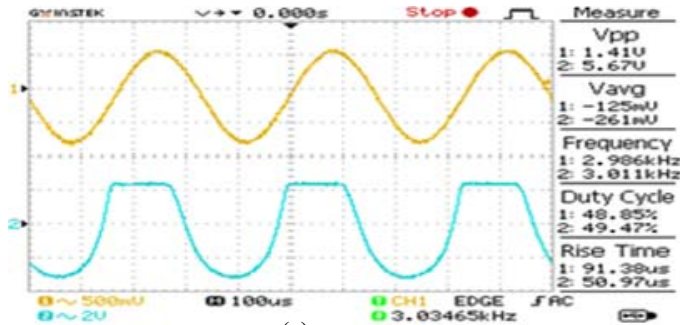

(a)

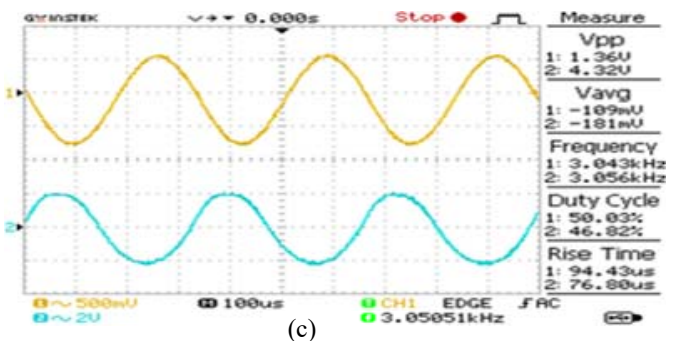

(c)

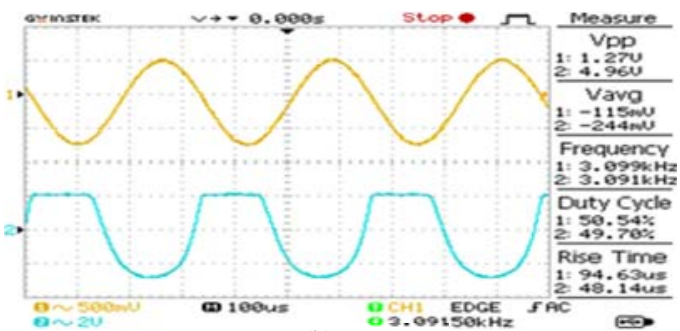

(b)

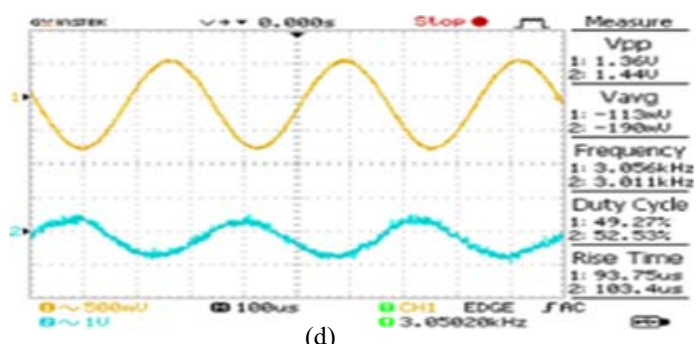

(d)

Figure 7. VLC Transceiver Signal Applying:

(a). diameter: $1 \mathrm{~m} 52 \mathrm{~mm}$ reflector, (b). diameter: $1 \mathrm{~m} 31 \mathrm{~mm}$ reflector,

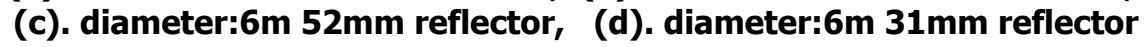

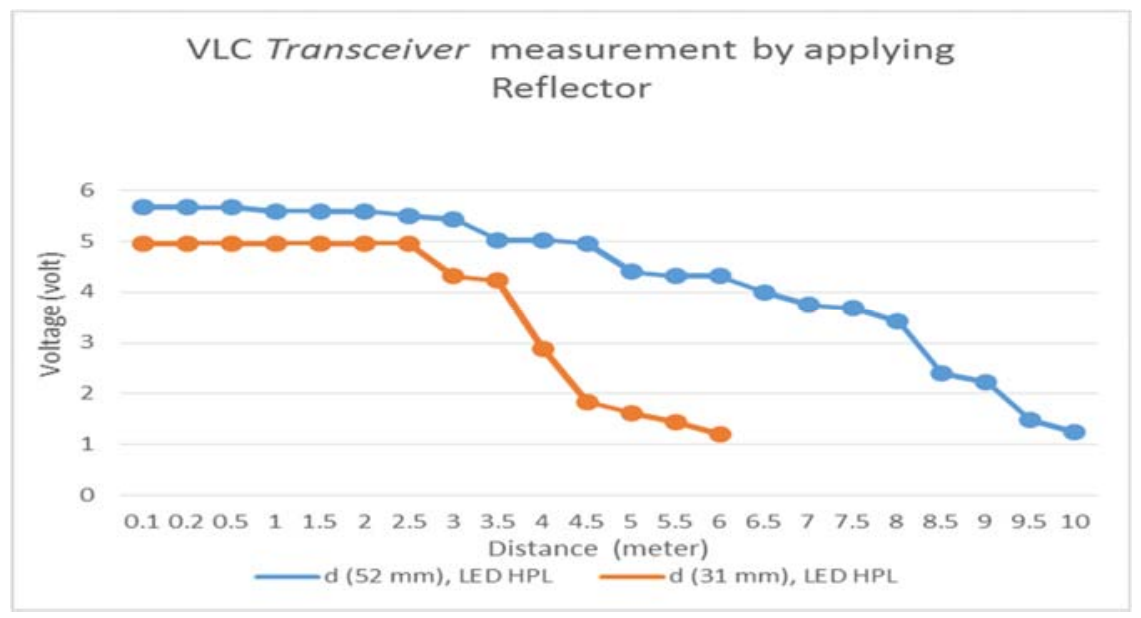

Figure 8. Signal Measurement Applying Reflector

Based on those experiments, the measurement of applying reflector (Figure 8 ) shows the stable received voltage that is achieved by $52 \mathrm{~mm}$ reflector with the diameter of 6 meters on average. The maximum distance that can be achieved by this $52 \mathrm{~mm}$ reflector is 9.5 meters. However, the $32 \mathrm{~mm}$ reflector has the maximum distance of 6 meters which is mainly caused by noise. 


\subsection{Distance Extension by Adding Photodiode Number}

The aim of this third experiment is to evaluate the signal reception by adding the number of photodiodes that is put in particular position according to LED's position. Figure 9 shows the measurement of using two $3 \mathrm{~mm}$ and $5 \mathrm{~mm}$ photodiodes.

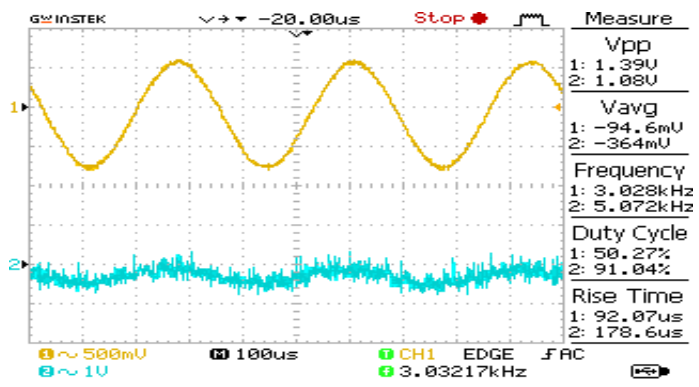

(a)

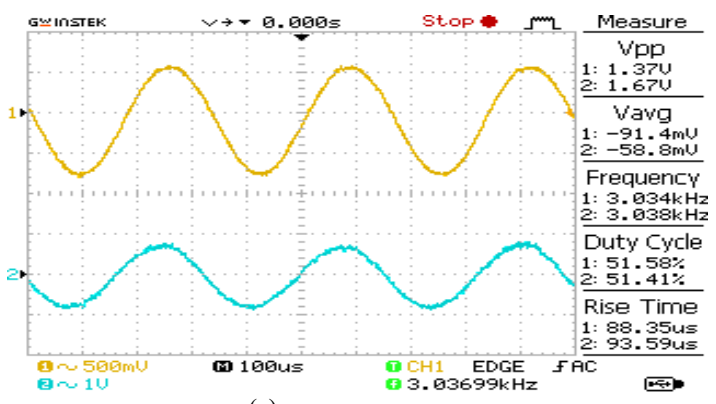

(c)

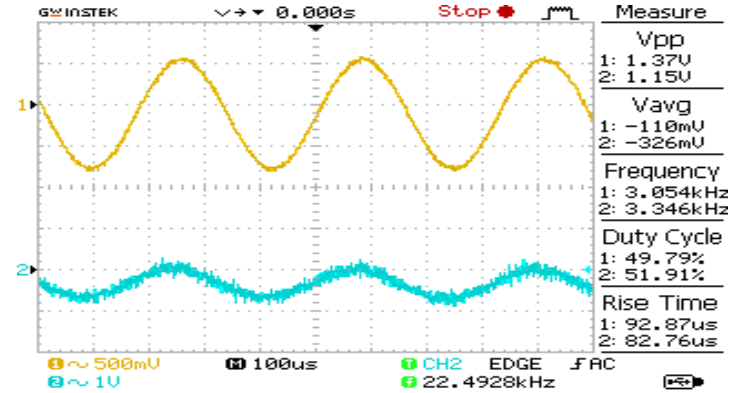

(b)

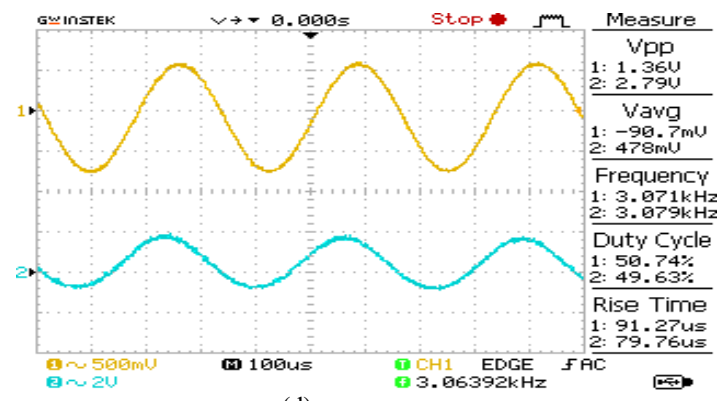

(d)

Figure 9. VLC Transceiver Signal Measurement using: (a). 3 meter 1×2 3mm Photodiode, (b). 3 meter $2 \times 23 \mathrm{~mm}$ Photodiode, (c). 3 meter 1×2 5mm Photodiode, (d). 3 meter 2x2 5mm Photodiode

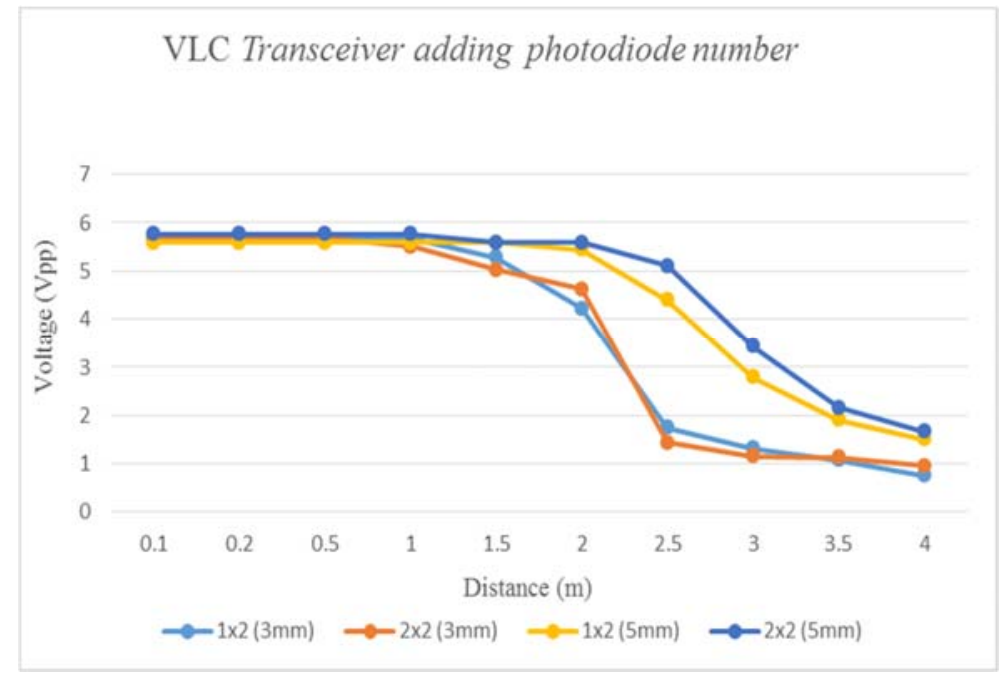

Figure 10. Signal Measurement Towards Photodiode Numbers 
By adding the number of photodiodes, the signal measurement as shown in Figure 10, represents the voltage attenuation using at the distance of 1.5 meters. It can be noticed that the attenuation shows the drastic decrease at the distance of 2.5 meters. However, the $2 \times 2$ $5 \mathrm{~m}$ photodiodes performs better than other types of photodiodes since the VLC receiver captures light in the wider scopes.

\subsection{Distance extension by applying solar cells}

The last experiment is applying solar cells as the alternative of using photodiodes. The solar cell is arranged on the VLC receiver side as illustrated in Figure 11.

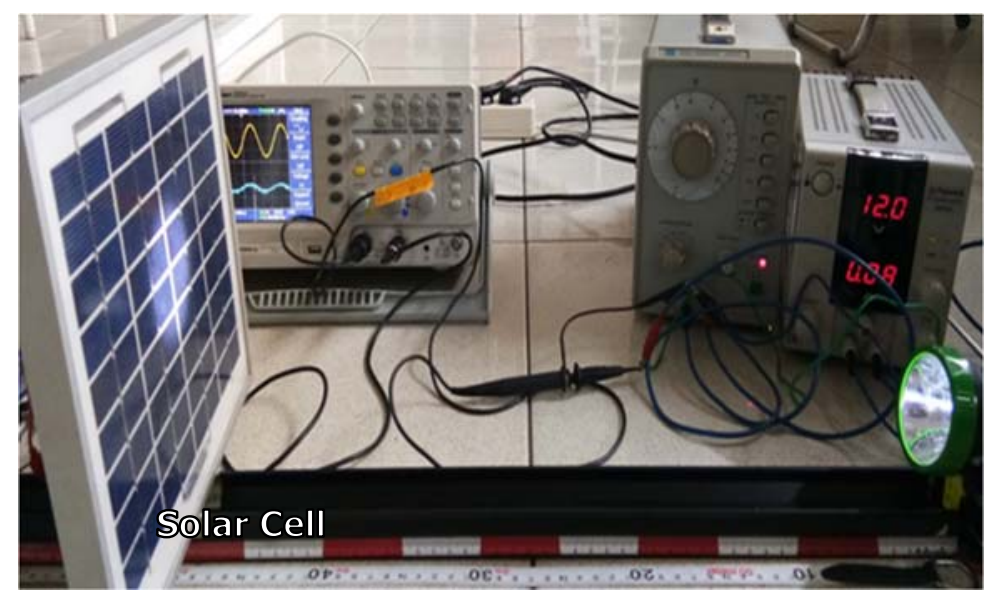

Figure 11. The Implementation of Solar Cells

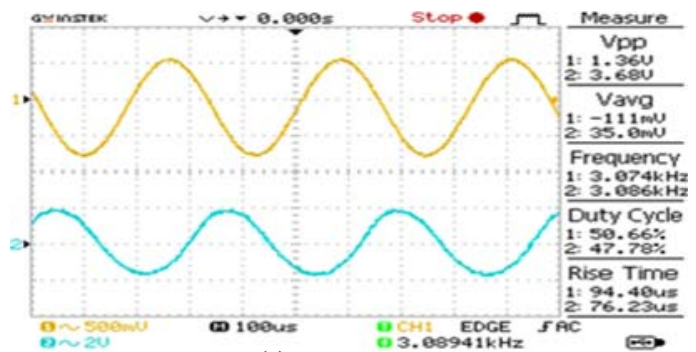

(a)

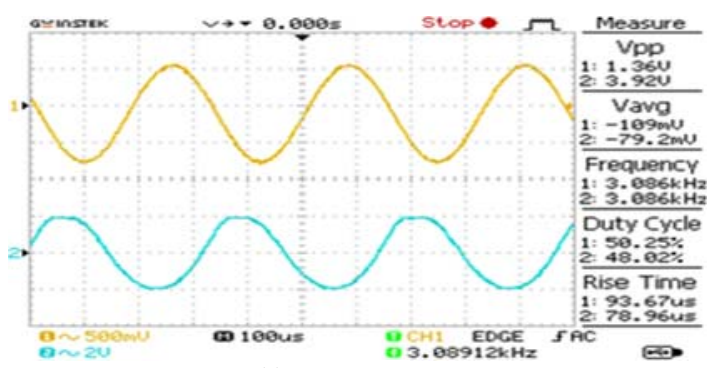

(c)

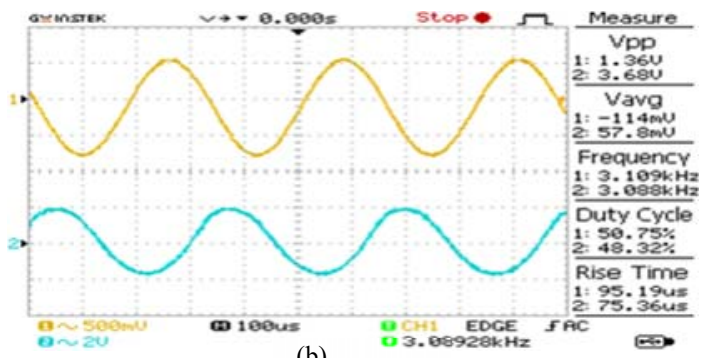

(b)

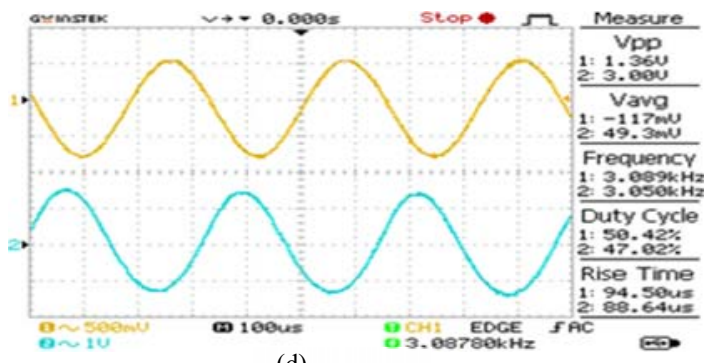

(d)

Figure 12. VLC Transceiver Signal Measurement using:

(a). $50 \mathrm{~cm}$ Solar cell, (b). $1 \mathrm{~m}$ Solar cell, (c). $2 \mathrm{~m}$ Solar cell, (d). $4 \mathrm{~m}$ Solar cell 
The measurements which are viewed on the oscilloscope are shown in Figure 12.

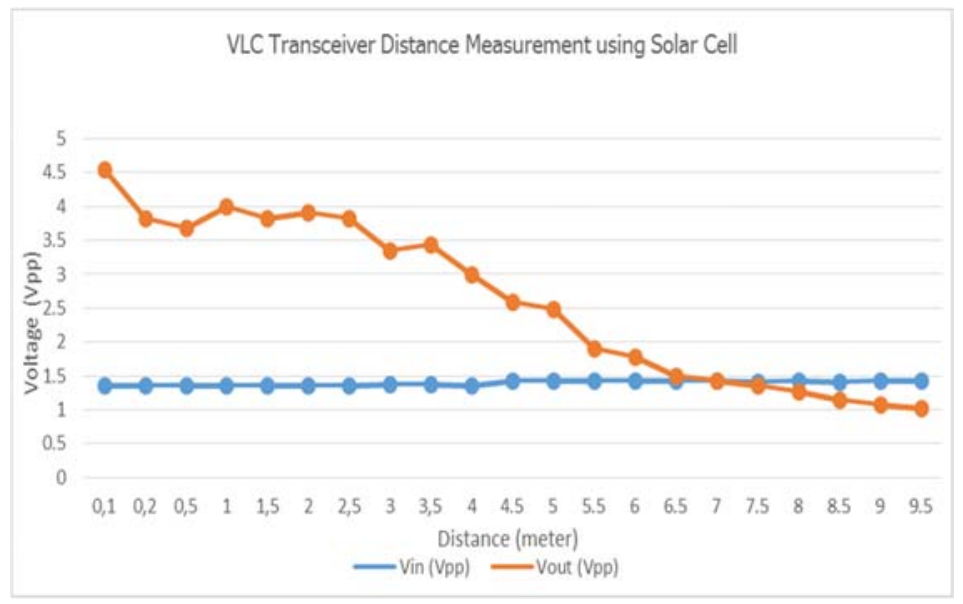

Figure 13. Signal Measurement using Solar cell

Figure 13 shows the result of signal measurement using solar cell instead of photodiode. The output voltage $\left(\mathrm{V}_{\text {output }}\right)$ shows inconstantly voltage rate at distance $10 \mathrm{~cm}$ to $5 \mathrm{~m}$. In addition, the signal quality decreases as the distance increases from $5.5 \mathrm{~m}-9.5 \mathrm{~m}$. The poor signal quality occurs because of the low light intensity due to the further distance between VLC transmitter and receiver. Moreover, the solar cell receiver is highly interfered by the surrounding environment we assumed as temperature when the device is located in the outdoor. The maximum distance of VLC transceiver using the solar cell is $9 \mathrm{~m}$ and it is indicated as the signal attenuation because the signal is decreased below 1V (Figure 13).

\section{CONCLUSION AND FUTURE WORK}

This work implemented the VLC transceiver and evaluated the different distance extension methods. The transmitted signal worked on the $3 \mathrm{kHz}$ audio frequency. The evaluation showed different maximum distances of each extension method. However, the VLC transceiver reached the maximum distance of $9.5 \mathrm{~m}$ which was obtained by applying $5 \mathrm{~mm}$ photodiode. It is also concluded that the size of the reflector has the significant impact to the light beam since it gained the stable voltage.

In future, the VLC transceiver will be implemented in a real environment i.e., on a road side unit (RSU) infrastructure.

\section{ACKNOWLEDGEMENTS}

This research is fully funded by The Ministry of Research and Education of the Republic of Indonesia in Hibah Penelitian Terapan Unggulan Perguruan Tinggi (PTUPT) 2019. 


\section{REFERENCES}

A.R., Darlis, W.A., Cahyadi, Y.H., Chung. (2018). Shore-to-Undersea Visible Light Communication. Wireless Personal Communication. 99(1), 681-694. https://doi.org/10.1007/s11277-017-5136-9.

W.H Shen, H.M Tsai. (2017). Testing Vehicle-to-Vehicle Visible Light Communications in Real-World Driving Scenarios. IEEE Vehicular Networking Conference (VNC).

Uysal, M, et.al., (2016). Visible Light Communication for Vehicular Networking_ Performance Study of a V2V System Using a Measured Headlamp Beam Pattern Model. IEEE Vehicular Technology Magazine. Doi: 10.1109/MVT.2015.2481561

A. R. Darlis. (2018). Bidirectional Underwater Visible Light Communication. International Journal of Electrical And Computer Engineering (IJECE). 8(6), 5203-5214.

Arnon, Shlomi, ed. (2015). Visible light communication. p. 1, Cambridge University Press.

Sindhubala K., \& Vijayalakshmi, B. (2015). Ecofriendly Data Transmission in Visible Light Communication.

Min-Soo, Kim., \& Kyung-Rak, Sohn. (2015). Performance Investigation of Visible Light Communication Using Super Bright White LED and Fresnel Lens. Journal of the Korean Society of Marine Engineering. 39(1), 63-67.

Fuada, Syifaul., Putra, Angga Pratama., Aska, Yulian., \& Adiono, Trio. (2016). Transimpedance Amplifier (TIA) Design for Visible Light Communication (VLC) using Commercially Available OP-AMP. Int. Conf. on Information Tech., Computer, and Electrical Engineering (ICITACEE).

Mossaad, Mohammed., Lampe, Lutz., \& Hranilovic, Steve. (2015). Amplify-and-Forward Integration of Power Line and Visible Light Communications. GlobalSIP.

Yong-hyeon, Kim., Yeon-Ho, Chung., \& Cahyadi, Willy Anugrah. (2015). Experimental Demonstration of VLC-Based Vehicle-to-Vehicle Communications Under Fog Conditions. IEEE Photonics Journal. 76$)$.

E. Hecht. (1997). Optics 3nd edition. Addison-Wesley (Reading, MA).

Max Born and Emil Wolf. (1999). Principles of Optics 7th edition. UK: Cambridge University Press. 